that continued to distort the general perception of the revival. Third, Šidak was the greatest authority on the history of Croatian historiography. He was painfully aware that after him there would be hardly any candidates capable of writing an informed overview of this topic. It is a great cultural loss that his time ran out before the completion of this task.

Šidak's research alone would have sufficed more than one lifetime, but he was more than an authoritative scholar. Generations of students and colleagues--including many visitors from abroad-will remember him as an outstanding lecturer, adviser, mentor, gentleman, and friend. A pianist and the editor of Jugoslavenski muzičar in the 1920s, he had the ear for language, having set the aesthetic standard for historical writing in contemporary Croatian. But, most important, he gave institutional shape to a profession in rapid expansion in a period of many constraints. As the editor and founder of Historijski zbornik, the best historical journal in Yugoslavia, he encouraged the best work available, brooking no interference from any quarter. Šidak had little patience with les grands simplificateurs of various hues. This exposed him to many indignities, but his sovereign sway in historiography was almost never challenged intellectually. Jaroslav Šidak prized truth above all else: hence his characteristic stance of wonder that so many subverted this ideal so often.

Ivo BANAC

Yale University

\title{
EDGAR H. LEHRMAN, 1926-1986
}

Professor and chairman of the Russian Department at Washington University in St. Louis, Edgar H. Lehrman died of brain cancer on 24 July 1986, at age sixty. While in the USSR in 1962-1963 under the terms of the American-Soviet academic exchange, he married Ruth Makarova, a Moscow University student. True to form, the Soviet authorities tried hard to break up the international romance but ultimately relented and allowed the bride to depart. She survives, as do their three daughters, Tanya, Ellen, and Julie.

A native New Yorker, Edgar H. Lehrman held a bachelor's degree in English from Cornell and an M.A. as well as a doctorate in Slavic languages and literatures from Columbia. His dissertation dealt with Russian Shakespeare scholarship, and he also edited a volume of Turgenev's letters. There is no doubt, however, that he will be long and gratefully remembered, above all, as the author of guides to the Russian texts of several Russian literary classics, including Crime and Punishment, War and Peace, and a representative collection of eighty-six of Chekhov's short stories, the latter published shortly before his untimely death. All of these were intended as a teaching aid that would enable an American student with two to three years of college Russian, and armed only with a standard Russian-English dictionary, to negotiate his way through the original texts of these works, helping him with difficult idioms, grammatical irregularities, slang, references to exotic realia or to mysteries of history and geography. Compiling these was a heroic task, but Lehrman viewed it as his scholarly mission. The guides are, indeed, models of pedagogy that required inexhaustible patience and wide erudition. Edgar $\mathrm{H}$. Lehrman played another unique role. For seventeen years he served as a reviewer of Russian books-and books dealing with Russia-for the St. Louis Post-Dispatch. Alone in the United States, Lehrman had access to pages of a major daily that he used to inform readers not only of the usual literary and political best sellers, but also of serious scholarly studies in the field of Russian culture, history, and politics. An exceptionally modest and warm person, Lehrman was one of the few serious scholars whose work directly benefited 
many thousands of ordinary citizens, to say nothing of undergraduates. All too often this honorable task fails to receive the recognition it deserves.

MaUrice Friedberg

University of Illinois at Urbana-Champaign 